\title{
The Burnout Levels of Emergency Employees in COVID -19 Pandemic and the Related Factors
}

\section{COVID-19 Pandemi Döneminde Acil Servis Çalışanlarının Tükenmişlik Düzeyleri ve Etkileyen Faktörler}

\author{
Metin OCAK ${ }^{1}(\mathbb{D})$, Nur Şimşek YURT ${ }^{2}(\mathbb{D})$, Yusuf Can YURT ${ }^{1}(\mathbb{D})$, Hacı Mehmet ÇALIŞKAN ${ }^{3}$ (D)
}

\author{
${ }^{1}$ Gazi State Hospital, Emergency Clinic, Samsun, TURKEY \\ 2 Samsun Training and Research Hospital, Family Medicine Clinic, Samsun, TURKEY \\ ${ }^{3}$ Ahi Evran University Faculty Of Medicine, Department of Emergency Medicine, Kırşehir, TURKEY
}

\section{Abstract}

Background: In this study we aimed to investigate burnout levels of the emergency employees during the pandemic period and the related factors.

Materials and Methods: 140 emergency service employees working in two large pandemic hospitals in Samsun province were included in the study. Maslach Burnout Inventory was performed on the participants.

Results: A total of 140 people participated in the study, wherein $55 \%$ are males and $45 \%$ are females, $55.8 \%$ are married, and $40.7 \%$ of them are in the age group of $18-27$ years and $30 \%$ are $28-37$ years. In occupational examination of participants, nurses rank first at the rate of $32.1 \%$ and practitioners rank second at $28.5 \%$. In addition, $40.7 \%$ of participants got infected with COVID-19 during the pandemic. Maslach burnout inventory was compared by demographic data, occupation, and medical history of COVID -19 of the participants. In consequence of the comparison of Maslach burnout inventory by demographic data, occupation, and COVID19 infection medical history of participants, statistically significant difference was found between gender ( $p=$ $0.003)$, educational backgrounds $(p=0.006)$, and COVID-19 disease history $(p=0.024)$ in the EE subscale, between gender $(p=0.038)$ and educational backgrounds $(p=0.003)$ in the desensitization subscale, and between genders $(p=0.007)$ in the personal success subscale. In addition, multivariate linear regression analysis showed that gender $(\beta=0.247, p=0.003)$ and COVID-19 disease history $(\beta=0.219, p=0.011)$ were independent predictors for emotional exhaustion.

Conclusions: In this study, we found that gender, educational background, and history of COVID-19 infection affect burnout. Also; We found that history of COVID-19 infection and gender are an independent predictor of emotional exhaustion.

Key Words: Emergency Service, COVID-19, Burnout, Pandemi

Öz.

Amaç: Biz bu çalışmada pandemi döneminde acil servis çalışanlarının tükenmişlik düzeyleri ve etkileyen faktörlerini araştırmayı amaçladık.

Materyal ve Metod: Samsun ilindeki iki büyük pandemi hastanesinde çalışan 140 acil personeli araştırmaya dahil edilmiştir. Katılımcılara Maslach tükenmişlik envanteri uygulanmıştır.

Bulgular: Çalışmaya \%55 erkek, \%45 kadın toplam 140 kişi katılmıştır. Katılımcıların \% 55.8'i evlidir. \%40.7'si 1827 yaş grubundayken \%30'u 28-37 yaş grubundadır. Gönüllülerin \%32.1'i hemşire \%28.5 pratisyen hekimdir. Katılımcıların \%40.7'si COVID-19 enfeksiyonu geçirmiştir. Maslach tükenmişlik ölçeğininin katılımcıların demografik verileri, mesleği ve COVID -19 geçirme öyküsüne göre karşılaştırılması sonucunda duygusal tükenme alt ölçeğinde cinsiyet ( $p=0.003$ ), eğitim durumları $(p=0.006)$ ve COVID-19 enfeksiyonu geçirme öyküsü $(p=0.024)$ arasında, duyarsızlaşma alt ölçeğinde cinsiyet $(p=0.038)$ ve eğitim durumları $(p=0.003)$ arasında, kişisel başarı alt ölçeğinde cinsiyetler ( $p=0.007)$ arasında istatistiksel anlamlı farklılıklar tespit edilmiştir. Ayrıca duygusal tükenme için cinsiyet ( $\beta=0.247, P=0.003)$ ve COVID-19 $(\beta=0.219, P=0.011)$ enfeksiyonu geçirme öyküsünün bağımsız prediktör olduğu tespit edilmiştir.

Sonuç: Bu çalışmada, cinsiyet, eğitim durumu ve COVID-19 enfeksiyon öyküsünün tükenmişliği etkilediğini bulduk. Ayrıca COVID-19 enfeksiyonu geçirmenin ve cinsiyetin duygusal tükenmenin bağımsız öngörücüsü olduğunu tespit ettik.

Anahtar kelimeler: Acil Servis, COVID-19, Tükenmişlik, Pandemi

Sorumlu Yazar/Corresponding Author

Dr. Metin OCAK

Gazi State Hospital, Emergency Clinic Samsun, TURKEY

post code 55100

E-mail: mdmocak@gmail.com

Geliş tarihi / Received: 16.04.2021

Kabul tarihi / Accepted: 21.06.2021

DOI: 10.35440/hutfd.917806 


\section{Introduction}

Burnout, as first described by Freudenberger in 1974, is a psychological condition comprising a long-term response to interpersonal permanent stressors. Fredenberger (1975) summarized the signs of burnout such as hopeless, fatigued, bored, resentful, disenchanted, discouraged, confused quickness to anger, instantaneous irritation, frustration responses, totally negative attitude, etc. (1). Burnout was further developed independently by Maslach to be characterized by three domains: emotional exhaustion (EE), depersonalization, and a diminished sense of personal accomplishment (2). EE component is considered as the most basic and distinct dimension and symptom of burnout syndrome. Desensitization component represents the interpersonal dimension of burnout syndrome. The personal success component reflects a person's tendency to feel inadequate (3). Health sector is one of the most important areas of service sector. Recently, working environment and conditions has been observed as getting difficult for health care professionals in terms of increasing work load, working under pressure, patient violence and suffering affronts from patients, struggling to meet patient's demands and hospital administration, etc. (4). Health care is listed as one of the most stressful occupations that require strong personal interaction with people, particularly with patients suffering from intensive stress and other health care providers, leading to high levels of burnout (5). Emergency services are areas where work load and stress are more common than others due to several reasons, such as intensive working environment, long hours, variability and unpredictability of cases, and need for rapid response to patients. In literature, studies indicated that emergency physicians suffer high levels of burnout syndrome $(6,7)$. In addition, cases of Coronavirus Disease 2019 (COVID-19) pandemic, which emerged in China later in 2019 and regarded as a pandemic by the World Health Organization on March 11, 2020, are still increasing all over the world (8). The pandemic brought with it many additional stress factors to health care professionals such as overworking, unable to take annual leave, distancing from families for a long time, working with personal protective equipment, colleagues falling sick or dying due to COVID-19 infection, worrying for infecting acquaintances with COVID-19 infection, etc. (4). In addition, the end of this pandemic is still unclear in spite of the positive vaccine and drug study developments. Emergency service employees experiencing high levels of burnout together with all these problems is inevitable. Literature in Turkey and worldwide is rich in studies related to burnout syndrome. Recently, studies on burnout syndrome began to be carried out with COVID-19 infection, as well $(4,5)$. This study aimed to investigate burnout levels of emergency service employees working in two large pandemic hospitals in Samsun province during COVID-19 pandemic and its influencing factors. In addition, this study is the first study investigating the influence of medical history of COVID-19 on burnout syndrome to the best of our knowledge.

\section{Materials and Methods}

This is a cross sectional survey study participated by the emergency service employees in Gazi State Hospital and Samsun Training and Research Hospital. The study was carried out between the dates 01.02.2021 and 01.03.2021. Questionnaires and burnout scales related to the demographic data and medical history of COVID-19 infection of participants were prepared on the internet and given to participants. A total of 140 volunteers, who meet the conditions of the study were contacted with their answers recorded. (This number of participants constitutes $39.4 \%$ of the population of the study)

Participants who had previous psychiatric diagnosis, refused to participate in the study, and left some of the survey questionnaires blank were excluded from the study.

Ethics committee approval required for the study was obtained from Health Sciences University, Samsun Training and Research Hospital, Non-Interventional Clinical Research Ethics Committee with the resolution no. 2021/1/14 dated January 13, 2021.

Maslach burnout inventory was used as a burnout scale, which was developed by Maslach and Jackson and is a 7point Likert scale consisting of 22 items. In its unique form, the scale consists of answer options "never, a few times a year, once a month, a few times a month, once a week, a few times a week, and every day". It comprises 3 subscales as follows: EE, Desensitization, and Personal Success. EE consists of 9 items; desensitization consists of 5 items and personal success consists of 8 items. Ergin made some modifications in the scale in his adaptation study. The 7-point answer options in the scale were modified as a 5-point scale as "never, rarely, sometimes, often, and always" (9). 5-point Likert scale was used in this study. Each item of the subscales was scored as $\mathbf{0 - 4}$. High level of burnout syndrome reflects high scores in the subscales of EE and desensitization and low score in the subscale of personal success. Three different burnout scores are estimated for each person in the scoring.

The program International Business Machines Corporation Statistical Package for the Social Sciences (Chicago, IL, USA) version 21.0 was used in the statistical analysis of data. Descriptive statistics are presented with mean, standard deviation, minimum-maximum, and median values for continuous data, and with percentage values for categorical data. Conformity of continuous data to normal distribution was evaluated by Kolmogorov-Smirnov test. Mann-Whitney $U$ test was used for comparison of two independent groups and Kruskal Wallis-H test was used for comparison of more than two groups. Categorical variables were compared using the chi-square test. Post-hoc analysis was performed to determine the significance of a group. Bonferroni correction was applied to the post-hoc analyses. Multivariate logistic regression analysis was used to determine the independent predictor of EE. $P<0.05$ was considered statistically significant. 


\section{Results}

A total of 140 people participated in the study, wherein $55 \%$ are males and $45 \%$ are females, $55.8 \%$ are married, and $40.7 \%$ of them are in the age group of $18-27$ years and $30 \%$ are 28-37 years.From the educational background examination of participants, university graduates rank first at the rate of $57.2 \%$ and post graduates rank second at the rate of $25.7 \%$. From the participants, $81.4 \%$ work in the secondary care state hospital and the rest work in the tertiary care state hospital. In occupational examination of participants, nurses rank first at the rate of $32.1 \%$ and practitioners rank second at $28.5 \%$. In addition, $40.7 \%$ of participants got infected with COVID-19 during the pandemic. Demographic data, educational background, and occupational information of participants and their organizations are given in Table 1.

Participants were examined by using the sub parameters of Maslach burnout inventory. According to the EE subscale, the following has the highest burnout levels: Gender: female (median: 22.5); Marital Status: married (median: 21); Occupation: medical secretaries (median: 26) and specialist doctors (median: 23); Hospital: tertiary care state hospital (median: 21.5); Age group: $18-27$ years (median: 21 ) and 38-47 (median: 21); and Education: primary school (median: 23) and vocational school (median: 22.5). Results showed that those with COVID-19 infection history have higher level of EE (median: 21).

According to the desensitization subscale, the following has the highest burnout level: Gender: female (median: 9); Occupation: medical secretaries (median: 13) and physician associates (median: 9.5); Hospital: tertiary care state hospital (median: 9); Age group: 18-27 years (median: 9); and Education: primary school (median: 10), secondary school (median: 10), and vocational school (median: 10). Results showed that those with COVID-19 infection history have higher level of desensitization (median: 9). In addition, marital status was found to have no effect on desensitization (median: 8).

According to the personal success subscale, the following has the highest burnout level: Gender: female (median: 20); Marital Status: single (median: 20.5); Occupation: practitioners (median: 20) and specialist doctors (median: 20.5); Hospital: tertiary care state hospital (median: 21); Age group: >47 years (median:19.5); and Education: university (median: 21) and post graduate (median: 21). Results showed that those with COVID-19 infection history have higher level of burnout according to the personal success subscale (median: 21).

Maslach subscale scores of the employees by variants are shown in Table 2. In consequence of the comparison of Maslach burnout inventory by demographic data, occupation, and COVID-19 infection medical history of participants, statistically significant difference was found between gen$\operatorname{der}(p=0.003)$, educational backgrounds $(p=0.006)$, and COVID-19 disease history ( $p=0.024)$ in the EE subscale, between gender $(p=0.038)$ and educational backgrounds $(p=$
$0.003)$ in the desensitization subscale, and between genders $(p=0.007)$ in the personal success subscale. A post-hoc analysis was carried out to investigate the reason for the difference in educational background, which was found to be caused by different secondary school and post graduate groups. The study found that EE and desensitization scores of the post graduate group are significantly high ( $p=0.002$ and $p=0.003$, respectively). No statistically significant difference was found among other parameters in comparison of the groups $(p>0.05)$ (Table.2).

In addition, multivariate linear regression analysis showed that gender $(\beta=0.247, p=0.003)$ and COVID-19 disease history $(\beta=0.219, p=0.011)$ were independent predictors for EE (Table 3).

Table 1. Demographic Data of Participants, Information on Education, Profession and Institution

\begin{tabular}{|c|c|c|}
\hline & $\begin{array}{l}\text { Number of Parti- } \\
\text { cipants (n) }\end{array}$ & Percent (\%) \\
\hline \multicolumn{3}{|l|}{ GENDER } \\
\hline Female & 63 & 45.0 \\
\hline Male & 77 & 55.0 \\
\hline \multicolumn{3}{|l|}{ Marital Status } \\
\hline Single & 62 & 44.2 \\
\hline Married & 78 & 55.8 \\
\hline \multicolumn{3}{|l|}{ Age } \\
\hline $18-27$ & 57 & 40.7 \\
\hline $28-37$ & 42 & 30.0 \\
\hline $38-47$ & 33 & 23.5 \\
\hline$<47$ & 8 & 5.8 \\
\hline \multicolumn{3}{|l|}{ Education } \\
\hline Primary School & 2 & 1.4 \\
\hline Secondary School & 5 & 3.5 \\
\hline High School & 9 & 6.4 \\
\hline Vocational School & 8 & 5.8 \\
\hline University & 80 & 57.2 \\
\hline Postgraduate & 36 & 25.7 \\
\hline \multicolumn{3}{|l|}{ Hospital } \\
\hline Stage 2 state hospital & 114 & 81.4 \\
\hline Stage 3 state hospital & 26 & 18.6 \\
\hline \multicolumn{3}{|l|}{ Year İn İnstitution } \\
\hline$<1$ Year & 34 & 24.3 \\
\hline$>9$ Year & 27 & 19.3 \\
\hline 1-3 Year & 40 & 28.6 \\
\hline 4-6 Year & 21 & 15.0 \\
\hline 7-9 Year & 18 & 12.8 \\
\hline \multicolumn{3}{|l|}{ Profession } \\
\hline Residency Student & 12 & 8.6 \\
\hline Security Guard & 2 & 1.4 \\
\hline Nurse & 45 & 32.1 \\
\hline Servant Staff & 6 & 4.3 \\
\hline Associate & 1 & 0.7 \\
\hline General Practitioner & 40 & 28.5 \\
\hline Health Officer & 13 & 9.3 \\
\hline Medical Secretary & 3 & 2.1 \\
\hline Specialist & 18 & 13.0 \\
\hline \multicolumn{3}{|c|}{ COVID-19 Disease History } \\
\hline Yes & 57 & 40.7 \\
\hline No & 83 & 59.3 \\
\hline
\end{tabular}


Table 2. Maslach Burnout Scale Scores Of The Participants According To Demographic Data, Hospital Status, Profession And COVID-19 Disease History

\begin{tabular}{|c|c|c|c|c|c|c|c|c|c|c|}
\hline & & \multicolumn{3}{|c|}{ Emotional Exhaustion } & \multicolumn{3}{|c|}{ Desensitization } & \multicolumn{3}{|c|}{ Personal Success } \\
\hline & & $\begin{array}{l}\text { Me- } \\
\text { dian }\end{array}$ & Min. & Max & $\begin{array}{l}\text { Me- } \\
\text { dian }\end{array}$ & Min & Max. & $\begin{array}{l}\text { Me- } \\
\text { dian }\end{array}$ & Min. & Max \\
\hline \multirow{3}{*}{ Gender * } & Male & 18 & 0 & 33 & 8 & 0 & 15 & 22 & 10 & 32 \\
\hline & Female & 22.5 & 3 & 35 & 9 & 2 & 17 & 20 & 10 & 29 \\
\hline & $P$ values & \multicolumn{3}{|c|}{0.003} & \multicolumn{3}{|c|}{0.038} & \multicolumn{3}{|c|}{0.007} \\
\hline \multirow{3}{*}{ Marital Status* } & Single & 20 & 3 & 35 & 8 & 2 & 16 & 20.5 & 10 & 31 \\
\hline & Married & 21 & 0 & 33 & 8 & 0 & 17 & 22 & 13 & 32 \\
\hline & $P$ values & \multicolumn{3}{|c|}{0.544} & \multicolumn{3}{|c|}{0.637} & \multicolumn{3}{|c|}{0.308} \\
\hline \multirow{10}{*}{ Profession** } & Residency Student & 20.5 & 11 & 31 & 9.5 & 5 & 13 & 21 & 16 & 24 \\
\hline & Security Guard & 15 & 13 & 17 & 1 & 1 & 1 & 22 & 17 & 27 \\
\hline & Nurse & 21 & 3 & 32 & 8 & 2 & 13 & 22 & 13 & 32 \\
\hline & Servant Staff & 4 & 0 & 23 & 2.5 & 0 & 11 & 23 & 18 & 31 \\
\hline & Associate & 13 & 13 & 13 & 5 & 5 & 5 & 26 & 26 & 26 \\
\hline & General Pract. & 19 & 10 & 35 & 8 & 3 & 16 & 20 & 10 & 28 \\
\hline & Health Officer & 22 & 8 & 29 & 9 & 3 & 17 & 23 & 19 & 30 \\
\hline & Medical Secretary & 26 & 25 & 33 & 13 & 4 & 13 & 23 & 16 & 24 \\
\hline & Specialist Doctor & 23 & 8 & 29 & 8.5 & 1 & 15 & 20.5 & 14 & 25 \\
\hline & P Values & \multicolumn{3}{|c|}{0.031} & \multicolumn{3}{|c|}{0.054} & \multicolumn{3}{|c|}{0.036} \\
\hline \multirow{3}{*}{ Hospital Status* } & Stage 2 state hospital & 20 & 0 & 33 & 8 & 0 & 17 & 22 & 10 & 32 \\
\hline & Stage 3 state hospital & 21.5 & 11 & 35 & 9 & 3 & 16 & 21 & 16 & 29 \\
\hline & $P$ values & \multicolumn{3}{|c|}{0.127} & \multicolumn{3}{|c|}{0.211} & \multicolumn{3}{|c|}{0.443} \\
\hline \multirow{5}{*}{ Age** } & $18-27$ & 21 & 3 & 35 & 9 & 2 & 16 & 21 & 10 & 31 \\
\hline & $28-37$ & 20 & 8 & 33 & 8 & 1 & 17 & 22 & 10 & 32 \\
\hline & $38-47$ & 21 & 0 & 29 & 8 & 0 & 13 & 22 & 14 & 31 \\
\hline & +47 & 20 & 3 & 29 & 4.5 & 1 & 15 & 19.5 & 13 & 22 \\
\hline & $P$ values & \multicolumn{3}{|c|}{0.996} & \multicolumn{3}{|c|}{0.095} & \multicolumn{3}{|c|}{0.257} \\
\hline \multirow{7}{*}{ Education** } & Primary School & 23 & 23 & 23 & 10 & 10 & 10 & 22 & 22 & 22 \\
\hline & Secondary School & 2 & 0 & 5 & 10 & 0 & 3 & 24 & 18 & 31 \\
\hline & High School & 21 & 13 & 33 & 4 & 1 & 13 & 22 & 16 & 27 \\
\hline & Vocational School & 22.5 & 10 & 29 & 10 & 4 & 13 & 23 & 18 & 30 \\
\hline & University & 20 & 3 & 35 & 8 & 2 & 17 & 21 & 10 & 32 \\
\hline & Post Graduate & 21 & 8 & 31 & 9 & 1 & 14 & 21 & 10 & 29 \\
\hline & $P$ values & \multicolumn{3}{|c|}{0.006} & \multicolumn{3}{|c|}{0.003} & & 0.353 & \\
\hline & No & 19 & 0 & 35 & 8 & 0 & 16 & 22 & 10 & 32 \\
\hline COVID-19 Disease & Yes & 21 & 8 & 35 & 9 & 1 & 17 & 21 & 13 & 29 \\
\hline History* & $P$ values & & 0.02 & & & 0.160 & & & 0.230 & \\
\hline
\end{tabular}

*Mann-Whitney U test, ${ }^{* *}$ Kruskal-Wallis test

Table 3. Multivariate Linear Regression Analysis Showing Independent Predictor of The Emotional Exhaustion

\begin{tabular}{lccccc}
\hline & \multicolumn{4}{c}{$\begin{array}{l}\text { Unstandardized } \\
\text { coefficients }\end{array}$} & \multicolumn{4}{c}{$\begin{array}{c}\text { Standardized co- } \\
\text { efficients }\end{array}$} \\
\hline & $\mathbf{B}$ & SE & $\boldsymbol{\beta}$ & $\mathbf{t}$ & $\mathbf{p}$ \\
\hline Gender & 3.425 & 1.147 & 0.247 & 2,987 & $\mathbf{0 . 0 0 3}$ \\
\hline Marital Status & 0.061 & 1.347 & 0.004 & 0.045 & 0.964 \\
\hline Profession & 0.445 & 0.242 & 0.156 & 1.836 & 0.069 \\
\hline Hospital Status & 2.846 & 1.528 & 0.162 & 1.862 & 0.065 \\
\hline Age & 0.073 & 0.734 & 0.010 & 0.100 & 0.921 \\
\hline Education & 0.601 & 0.655 & 0.083 & 0.918 & 0.361 \\
\hline $\begin{array}{l}\text { COVID-19 } \\
\text { Disease History }\end{array}$ & 3.063 & 1,184 & 0.219 & 2.586 & $\mathbf{0 . 0 1 1}$ \\
\hline
\end{tabular}

\section{Discussion}

In this study, gender, education status, and COVID-19 infection history was found to affect burnout. EE was found to be significantly higher in those with COVID-19 infection. However, desensitization and personal success categories were not affected by COVID-19 infection history. In addition, gender and COVID-19 history are independent predictors in the EE subscale. In previous studies, it has been reported that COVID-19 increases stress, anxiety and depression in people and negatively affects mental health (10). In another study that investigated the effect of COVID-19 on emergency service workers in Turkey; It was reported that $53.7 \%$ of the employees had mild anxiety, $28.4 \%$ had moderate anxiety and $17.9 \%$ had severe anxiety (11). To the best of our knowledge, this study is the first to investigate the effect of COVID-19 infection history on burnout.

Considering the importance and function of the emergency services in Turkey, it is important to minimize the burnout level of emergency service employees in terms of both employees and people they serve.

Factors such as age, gender, educational background, marital status, number of children, excessive commitment to work, personal expectancy level, individual performance, personality traits, work-related stress, job satisfaction and motivation, and relationship and communication with colleagues and managers are among the individual and social reasons for burnout syndrome (12). 
Heavy working conditions and health problems caused by the pandemic that increase burnout due to many factors is inevitable. Study results showed that those with COVID19 infection history had significantly higher levels of EE. In addition, COVID-19 infection history was found as an independent EEpredictor. As far as we know, our findings are the first in this sense of literature.

In literature, many studies on the effects of gender on burnout are reported. Some studies reported that gender has no effects on burnout; however, females are reported to have higher levels of burnout $(3,12-17)$. This study also found that females have higher levels of burnout in all three subcategories in accordance with literature.

From previous studies, EE and desensitization generally decrease and personal success increases as educational level increases (18-20). This study found significant difference in burnout level among educational backgrounds. The difference was found to be caused by the difference between secondary school and post graduate groups. Unlike literature, post graduate group has higher level of $\mathrm{EE}$ and desensitization. The reason for this may be that the employees in the postgraduate education group do not perform jobs that are not in line with their educational background and professional satisfaction expectations. Among the groups in the personal success subscale, no difference was found. The effect of the profession and age on burnout has not been clearly defined. Studies in literature reported that nurses and general practitioner are occupational groups that are at the highest risk of burnout among health care professionals $(21,22,23)$. Another study reported that security guards have the highest level of burnout among occupational groups (18). Also, studies reported that occupation does not have any effects on burnout level (3). This study did not find a significant relationship between occupation and burnout syndrome. Many previous studies reported that burnout level decreases as people get older with more experience $(18,24,25)$. Öztürk et al. reported that age does not significantly affect burnout level (3). This study showed that age factor does not significantly affects burnout levels of participants.

Studies reported that effects of marital status on burnout level are unclear. Maslach et al. reported that single people have higher level of burnout than the married ones (2). Aslan et al. reported that single people have lower level of burnout (24). Türkmenoğlu et al. reported that marital status has no effects on burnout level (18). This study found that marital status does not significantly affect burnout level.

\section{Limitations}

Limited participation in this study is one of the most significant limitations. Besides, another significant limitations of the study is non-inclusion of factors such as the years of work in the profession, how long he worked in which department, working conditions, hospital management, etc., which affect burnout level. In addition, the fact that the participants could not be examined by a psychiatrist is another limitation of the study.

\section{Conclusion}

Result showed that burnout levels are significantly higher in female gender, post graduate education, and COVID-19 infection history. Other demographic data was found to have no significant effect. In addition, gender and COVID19 infection history are independent predictors in the EE subscale. To reduce burnout rates in emergency service workers struggling with COVID-19; It is very important to provide working conditions suitable for the professional satisfaction expectation and educational status of employees and to take protective measures to reduce the risk of COVID-19 transmission. In addition, we think that professional psychiatric support should be provided to protect and support the mental health of the employees.

Ethical Approval: Ethics committee approval required for the study was obtained from Health Sciences University, Samsun Training and Research Hospital, Non-Interventional Clinical Research Ethics Committee with the resolution no. 2021/1/14 dated January 13, 2021.

\section{Author Contributions:}

Concept: M.O., Y.C.Y.

Literature Review: M.O.,N.Ş.Y.,H.M.Ç.

Design : M.O.,Y.C.Y.,N.Ş.Y.

Data acquisition: M.O.,Y.C.Y.,N.Ş.Y.

Analysis and interpretation: M.O.,H.M.Ç.,N.Ş.Y.

Writing manuscript: M.O.

Critical revision of manuscript: N.Ş.Y.,H.M.Ç.

Conflict of Interest: The authors have no conflicts of interest to declare.

Financial Disclosure: Authors declared no financial support.

\section{References}

1. Leiter MP, Maslach C. Nurse turnover: the mediating role of burnout. J Nurs Manag. 2009 Apr;17(3):331-9.

2. Maslach $C$, Jackson Se. The Measurement Of Experienced Burnout. Journal Of Occupatıonal Behavıour.1981; 2 (2): 99-113

3. Öztürk O, Uyar El. Samsun İlindeki Bazı Toplum Sağlığı Merkezi Çalışanlarında Memnuniyet Düzeyi ve Tükenmişlik Durumu. TJFMPC. 2016;10(4): 213-21.

4. Yüncü V, Yılan Y. COVID-19 Pandemisinin Sağlık Çalışanlarına Etkilerinin Incelenmesi: Bir Durum Analizi. Igd Univ Jour Soc Sci. 2020; November (Supplement):373-401

5. Dinibutun SR. Factors Associated with Burnout Among Physicians: An Evaluation During a Period of COVID-19 Pandemic. J Healthc Leadersh. 2020 Sep 15;12:85-94

6. Kimo Takayesu J, Ramoska EA, Clark TR, Hansoti B, Dougherty J, Freeman W, Weaver KR, Chang Y, Gross E. Factors associated with burnout during emergency medicine residency. Acad Emerg Med. 2014 Sep;21(9):1031-5

7. Boutou A, Pitsiou G, Sourla E, Kioumis I. Burnout syndrome among emergency medicine physicians: an update on its prevalence and risk factors. Eur Rev Med Pharmacol Sci. 2019 Oct;23(20):9058-65.

8. WHO. Director - General's opening remarks at the media briefing on COVID-19 -11 March 2020 2020; Available 
from: https://www.who.int/dg/speeches/detail/who-director-general-s-opening-remarks-at-the-media-briefingon-covid-19-11-march-2020

9. Ergin, C. Doktor ve hemşirelerde tükenmişlik ve Maslach Tükenmişlik Ölçeğinin uyarlanması. VII. Ulusal Psikoloji Kongresi. Hacettepe Üniversitesi, Ankara; 1992 s. 143-154.

10. Salari N, Hosseinian-Far A, Jalali R, Vaisi-Raygani A, Rasoulpoor S, Mohammadi M, et al. Prevalence of stress, anxiety, depression among the general population during the COVID-19 pandemic: a systematic review and meta-analysis. Global Health. 2020 Jul 6;16(1):57.

11. Havlioğlu S, Demir HA. Determining the Anxiety Levels of Emergency Service Employees' Working During The Covid19 Pandemic. Journal of Harran University Medical Fakulty. 2020;17(2):251-255

12. Karahan H. Acil Servislerde Çalışan Sağlık Personellerinde Tükenmişlik Sendromu Görülme Sıklığı ve Demografik Özellikleri. Anatolian J Emerg Med. 2020;3(3); 81-84.

13. Maslach C. Burnout: A Social Psychological Analysis, The Burnout Syndrome: Current Reserch, Theory and Interventions. Park Ridge, III, London House Management. 1981:3152.

14. Oğuzberk $M$, Aydın A. Ruh Sağlığı Çalışanlarında Tükenmişlik. Klinik Psikiyatri. 2008;11:167-79.

15. Kocabıyık ZO, Çakıcı E. Sağlık çalışanlarında tükenmişlik ve iş doyumu. Anadolu Psikiyatri Dergisi. 2008;9(3):132-138

16. Maslach $C$, Leiter MP. The truth about burnout, San Francisco: Jose-Bass Publishers; 1997.

17. Kurçer M. Harran üniversitesi tıp fakültesi hekimlerinin iş doyumu ve tükenmişlik düzeyleri. Harran Univ Tıp Fak Derg. 2005;2(3):10-15.

18. Türkmenoğlu B, Sümer H. Sivas II Merkezi Sağlık Çalışanlarının Tükenmişlik Düzeyleri. Cumhuriyet Üniv. Sağ. Bil. Enst. Derg. 2017 (2)2: 24-34

19. Akbolat $M$, ışık $O$. Sağlık çalışanlarının tükenmişlik düzeyleri: bir kamu hastanesi örneği. Hacettepe Sağlık Idaresi Dergisi. 2008; 11:229-54.

20. Günüşen N, Üstün B. Bir Üniversite Hastanesinde Çalışan Hemşirelerin Tükenmişlik Düzeyi ve Etkileyen Faktörlerin Incelenmesi. Atatürk Üniversitesi Hemşirelik Yüksekokulu Dergisi. 2008; 11 (4): 48-58

21. Alacacıoğlu A, Yavuzsen T, Diriöz M, Öztop I, Yılmaz U. Burnout in nurses and physicians working at an oncology department. Psycho-Oncology. 2009;18:543-548

22. Aydın $A$, Oğuzberk $M$. Ruh sağlığı çalışanlarında tükenmişlik. Klinik Psikiyatri. 2008;11:167-79.

23. Girgin G, Özbek K. "Sağlık Bakanlığı İzmir II Teşkilatında Çalışan Hekimlerde Tükenmişlik (Burnout) Sendromunun Araştırılması", Ankara: T.C. Sağlık Bakanlığı Temel Sağlık Hizmetleri Genel Müdürlüğü Ruh Sağlığı Bülteni.

24. Aslan Ö, Lofçalı A, Uğur Ş, Tuğlu A. Hemşirelerin Acil Serviste Şiddet İçeren Olgu Senaryolarına Yaklaşımları. GüIhane Tıp Dergisi. 2005; 47(1): 18-23.

25. Ergin C. Maslach tükenmişlik ölçeğinin Türkiye sağlık personeli normları. Psikiyatri Psikoloji Psikofarmakoloji (3P) Dergisi. 1996; 4 (1): 28-33. 